\title{
Uso de Depoimento de Pacientes e Cuidadores como Ferramenta de Sensibilização e Humanização em Curso de Capacitação para Voluntários na Área de Saúde
}

\author{
Barbosa, Mauricio Einstoss de Castro; Costa, Natália Pereira; Brunetti, Gloria \\ Instituto de Infectologia Emílio Ribas — barbosabr@hotmail.com
}

Introdução Desde 2004 é realizado curso de capacitação para voluntários que atuarão em programas de humanização desenvolvidos pelo voluntariado de um hospital terciário especializado em doenças infecciosas em São Paulo. o objetivo é atender a todos os pacientes e cuidadores usuários do hospital. o foco deste trabalho é uma das ferramentas usadas no curso: depoimento de pacientes e de cuidadores sobre suas vidas e o impacto que a doença traz a elas, objetivando sensibilizar, humanizar e informar os participantes. Objetivos Principal Através de depoimento de pacientes e cuidadores, sensibilizar e informar potenciais voluntários para capacitá-los, com recursos tanto práticos como emocionais, a atuarem no hospital de forma consciente, eficiente e humanizada. Secundários - para voluntários: proporcionar desenvolvimento pessoal através de experiências de empatia com pessoas portadoras de doenças crônicas. - para pacientes: proporcionar oportunidade de desenvolver, num ambiente seguro e informal, sua capacidade de lidar com a própria patologia, suas dificuldades e o preconceito. - para o hospital: capacitar pessoas a trabalharem de forma mais humanizada com os pacientes ali atendidos. - para a sociedade: conscientizar, informar, sensibilizar e humanizar seus cidadãos. Metodologia: o curso coloca potenciais voluntários em contato com o paciente e sua patologia principalmente no 2 Módulo, 0 PACIENTE, durante o qual é realizada a palestra com o depoimento de pacientes ou cuidadores. Estes são previamente convidados, devendo ser maiores de idade e usuários do hospital. Seus depoimentos são espontâneos, falando de sua vida, como soube da patologia, como conviveu e convive com ela, destacando os preconceitos que sofre em sua vida pessoal e profissional. Resultados: no decorrer desses nove anos, foram coletados relatos sobre os depoimentos apresentados, que demonstram efeitos positivos para os pacientes, cuidadores, funcionários do hospital e voluntários. uma paciente diz que a oportunidade de falar abertamente sobre sua vida, sua patologia, a forma de contágio e preconceitos sofridos a fortaleceu muito, principalmente com a presença de seus filhos e amigos mais próximos na plateia. uma voluntária menciona que o conhecimento obtido a ajuda muito em seu trabalho voluntário, sentindo-se mais confiante no contato com os pacientes e eliminando julgamentos errôneos. para sua vida pessoal, diz que obteve aprendizado de superação e de resiliência, além da satisfação em levar adiante o conhecimento adquirido. Conclusão Acreditamos que os depoimentos apresentados em palestras para a sociedade por pessoas diretamente envolvidas no problema abordado, representam uma ferramenta de sensibilização e humanização importante, simples, de baixo custo e que traz resultados impactantes para todos os envolvidos, conforme os resultados que pudemos observar in loco e registrar através de relatos pós-evento.

Barbosa, Mauricio Einstoss de Castro; Costa, Natália Pereira; Brunetti, Gloria. Uso de Depoimento de Pacientes e Cuidadores como Ferramenta de Sensibilização e Humanização em Curso de Capacitação para Voluntários na Área de Saúde. In: Anais do Congresso Internacional de Humanidades \& Humanização em Saúde [= Blucher Medical Proceedings, num.2, vol.1]. São Paulo: Editora Blucher, 2014. ISSN 2357-7282

DOI 10.5151/medpro-cihhs-10399 